\title{
Social and economic complexity in early medieval England: a central place complex of the East Anglian kingdom at Rendlesham, Suffolk
}

Christopher Scull ${ }^{1}$, Faye Minter ${ }^{2} \&$ Judith Plouviez ${ }^{2}$

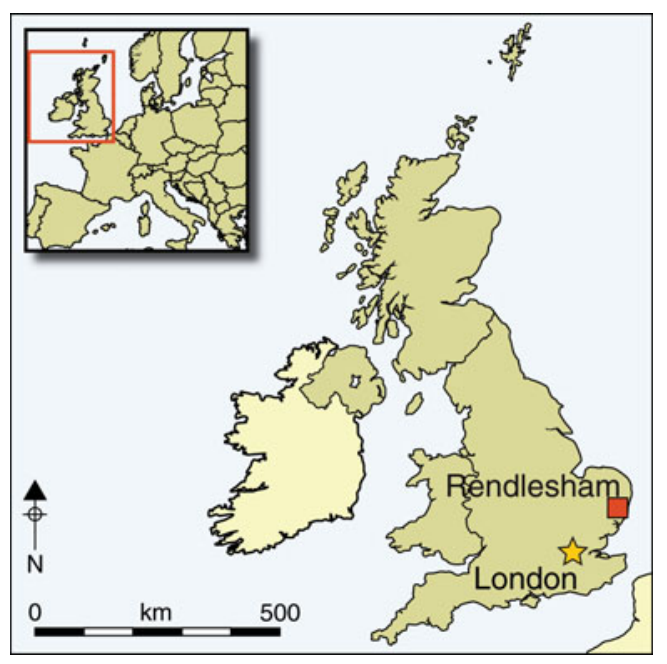

Fieldwork at Rendlesham in Suffolk has identified a major central place complex of the early-middle Anglo-Saxon periods. This has particular significance in the light of Bede's eighth-century reference to a 'royal settlement' at Rendlesham and the princely burial site at nearby Sutton Hoo. This interim report summarises the archaeology, and considers the wider interpretative issues relating to economic complexity and social diversity.

Keywords: England, Suffolk, early medieval, Anglo-Saxon

\section{Introduction}

The modern civil parish of Rendlesham lies on the east side of the River Deben in south-east Suffolk, about $6 \mathrm{~km}$ north-east of the elite barrow cemetery at Sutton Hoo (Figure 1). It incorporates terrains that in the past provided a range of resources: marsh or water meadow in the valley bottom; agricultural soils on valley slopes; and interfluves that are now intensively cultivated but which in the past were heathland and sheep-walk (Williamson 2008: 29-67). The parish sits within the Sandlings of south-east Suffolk, a region of subdued topography and light sandy soils with estuarine rivers flowing into the North Sea (Young 1797; Clarke 1960: 15-19; Williamson 2008: 29-33). It has been argued that the Sandlings region

1 Department of Archaeology \& Conservation, John Percival Building, Colum Drive, Cardiff University, Cardiff CF103EU,UK(Email: chris@chrisscull.co.uk)

2 Suffolk County Council Archaeological Service, 6 The Churchyard, Shire Hall, Bury St Edmunds IP33 IRX, $U K$ 


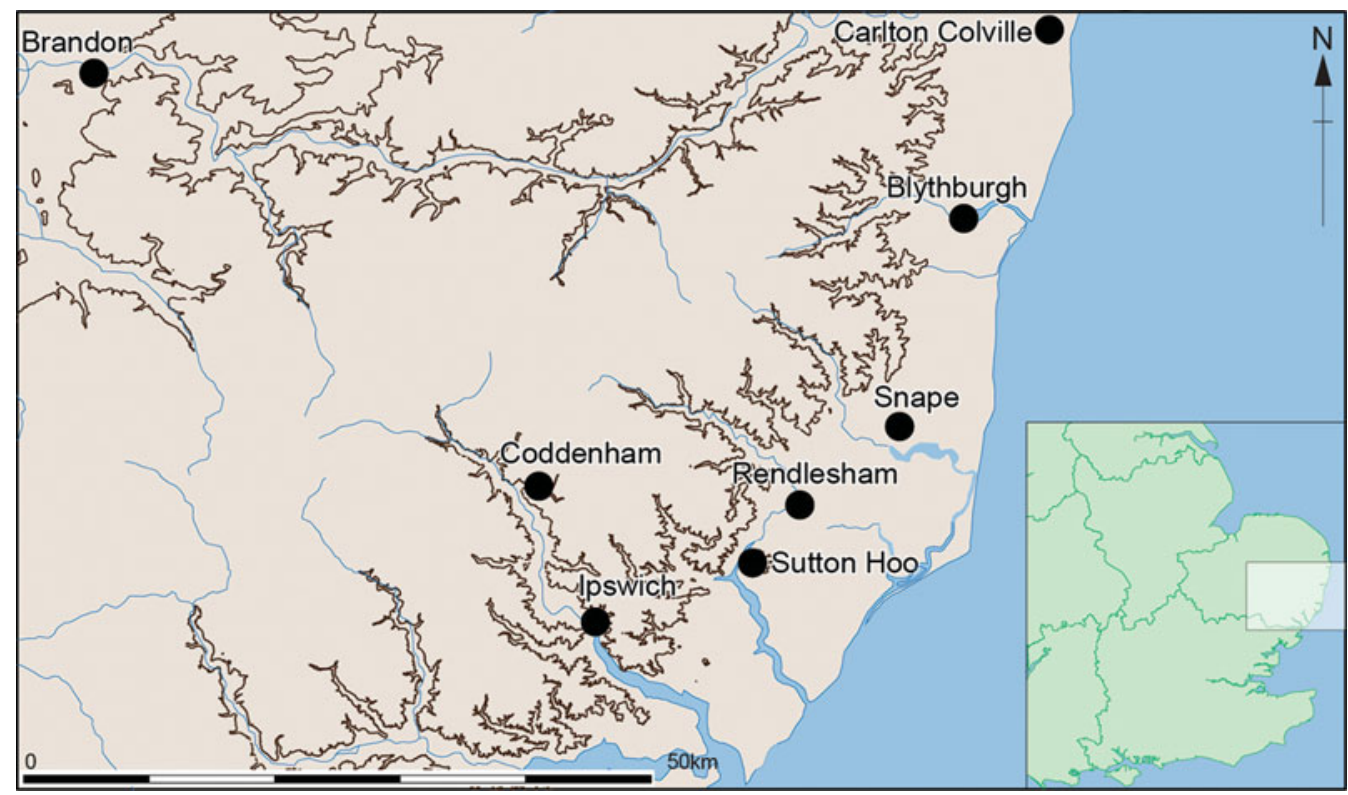

Figure 1. Map of Suffolk showing places mentioned in the text (contour line at 30m OD).

formed the territorial focus of East Anglian royal power in the seventh century (Carver 2005: 494-99; Scull in press).

Rendesham is mentioned by Bede (H.E. iii. 22; Colgrave \& Mynors 1969) as the East Anglian vicus regius (royal settlement) where King Swithhelm of the East Saxons was baptised in $\mathrm{AD} 655 \times 663$. It has consequently long been a focus of antiquarian and historical attention, and interest intensified after the discovery of the Mound One ship burial at Sutton Hoo in 1939 (Bruce-Mitford 1948). Cremations were recorded in the early nineteenth century, but otherwise hard evidence for an Anglo-Saxon site was frustratingly elusive until 1981-1982 when fieldwalking and limited excavation indicated Anglo-Saxon settlement activity northwest of the parish church of St Gregory the Great (Bruce-Mitford 1974; Martin et al. 1983: 235; Newman 1992: 36-38). Although the potential significance was clear, little about the material recovered suggested a site of unusual status.

This changed in 2007 when the landowner of the Naunton Hall estate sought archaeological assistance in response to illegal metal-detecting on arable land. Damage was being caused by repeat visits, suggesting that archaeological material was being stolen; and the land affected included fields outside the sector of the 1981-1982 fieldwalking, indicating that the area of potential archaeological significance was greater than had been thought. The response by Suffolk County Council Archaeological Service (SCCAS) was to undertake, in 2008, controlled metal-detector survey of the area being damaged, augmented by limited magnetometry, a desktop assessment of available maps and documentary evidence, and plotting of relevant aerial photography.

The initial metal-detecting survey confirmed a dense concentration of archaeological material in the ploughsoil, including coins and other finds consistent with a high-status early-middle Anglo-Saxon site. It also indicated that this evidence of past activity spread 
over a wider area than had been initially thought. In 2009, the metal-detector survey was therefore expanded to cover the full Naunton Hall estate. This was undertaken as part of a larger project, coordinated through SCCAS, which provided finds recording to Portable Antiquities Scheme (PAS) standards, and expert academic and professional guidance, and through which complementary fieldwork including further magnetometry and field evaluation were commissioned.

The main survey began in 2009, and fieldwork was completed in the summer of 2014. As this is a working farm, premature announcement of the project ran the risk of further damage to crops and archaeology from illegal detecting, and so details of the survey were kept confidential until the later stages of fieldwork. Results indicate a complex sequence of settlement and activity from late prehistory to the present day, but in this interim communication, we concentrate on the archaeology of the fifth-eighth centuries AD and the wider interpretative issues that it raises.

\section{Methods and results}

The survey area covers $150 \mathrm{ha}$ (Figure 2). It forms a transect $3 \mathrm{~km}$ north-south along the east side of the Deben Valley, and $1.25 \mathrm{~km}$ east-west across the grain of the landscape, a sample area large enough to provide confidence in patterns of presence, absence and clustering of finds, and to allow examination of changes in these patterns with terrain.

The main survey method was systematic

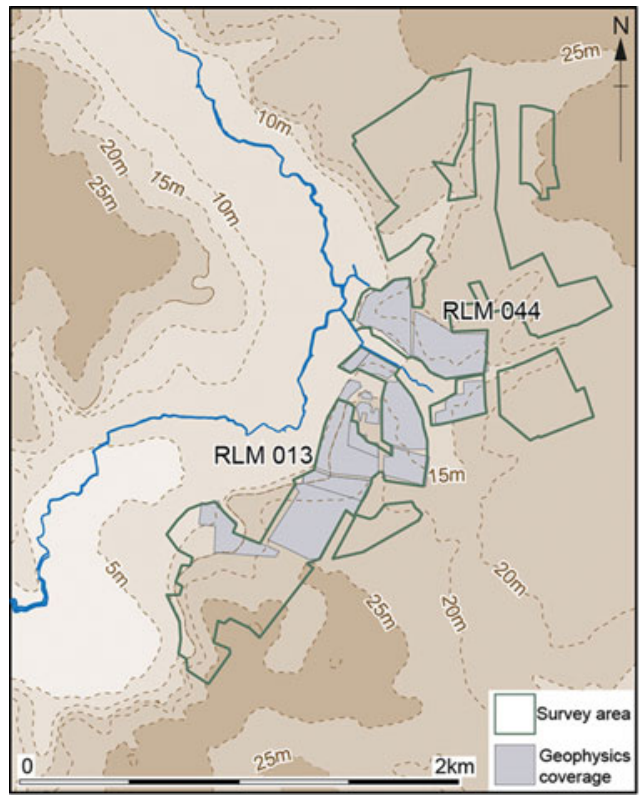

Figure 2. Map of the Deben Valley at Rendlesham showing the extent of the survey area and the locations of fields RLM 013 and RLM 044.

C) Antiquity Publications Ltd, 2016 surface collection with metal detectors, aiming for 100 per cent coverage. All survey units were surveyed at least twice, with the time spent, surface conditions, weather and crop recorded for each survey episode. The location of all finds pre-dating 1650including ceramics and lithics, as well as metal items-was recorded using a handheld GPS. Finds were catalogued on a MS Access database linked to a project GIS (MapInfo), which allows for the integration of all datasets. The database holds records of 3946 items dating from the Neolithic to Early Modern periods. Of the material that can be securely dated, 27 per cent is Anglo-Saxon (fifth-eleventh centuries AD), compared to only 5 per cent of finds recorded from Suffolk as a whole through the PAS. Most of the Anglo-Saxon material from Rendlesham is of the fifth-eighth centuries, indicating significant activity at that time. 


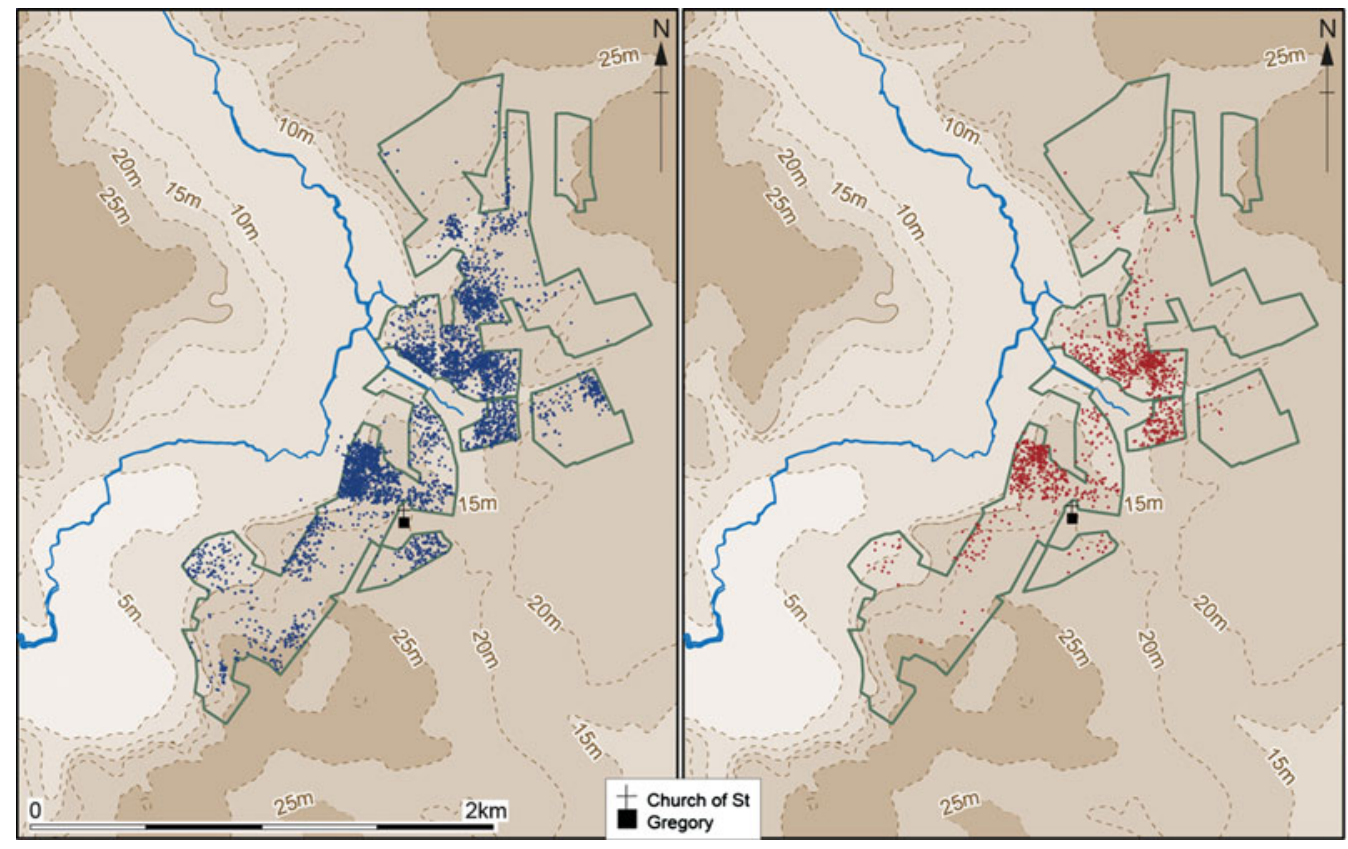

Figure 3. Map showing the distribution of survey findspots: left) all finds (blue); right) Anglo-Saxon finds (red).

Magnetometry and detailed topographic survey were undertaken over 46 ha to investigate the core area of Anglo-Saxon activity indicated by metal-detecting (Figures 2 \& 3). Magnetic response was generally good, and the results show an extensive palimpsest of enclosures, boundaries and settlement features (Figures 4 \& 5). Selected features were excavated in 2013 and 2014, along with six $10 \times 5 \mathrm{~m}$ trenches and one $10 \times 7.5 \mathrm{~m}$ trench that confirmed the accuracy of the magnetometry and provided information on the site's preservation, character, date and potential, allowing more confident interpretation of the geophysics on a wider scale. After the initial transcription of aerial photography as part of the pilot survey, the site was included in Historic England's regional flying programme, and in 2014 was added to the National Mapping Programme (NMP). In 2015, the NMP identified cropmarks that appear to be the foundations of a rectangular timber building, $23 \times 9.5 \mathrm{~m}$. While the interpretation is not certain, this is a good candidate for an Anglo-Saxon hall (Figure 5).

Surface geochemical survey, using portable X-ray fluorescence spectroscopy, was undertaken to determine whether significant concentrations of trace elements might point to areas of specific activity, in particular non-ferrous metalworking. The technique was effective in detecting heavier trace-elements in ploughsoil, but did not identify any significant spatial concentrations, and is unlikely to be useful as an extensive survey technique in the conditions at Rendlesham (Dunster et al. 2012).

\section{Layout and development of the site}

The distribution of fifth- to eighth-century finds suggests settlement activity over an area of around 50 ha (Figure 3). To the south, this is a flat promontory at approximately $10 \mathrm{~m}$ 


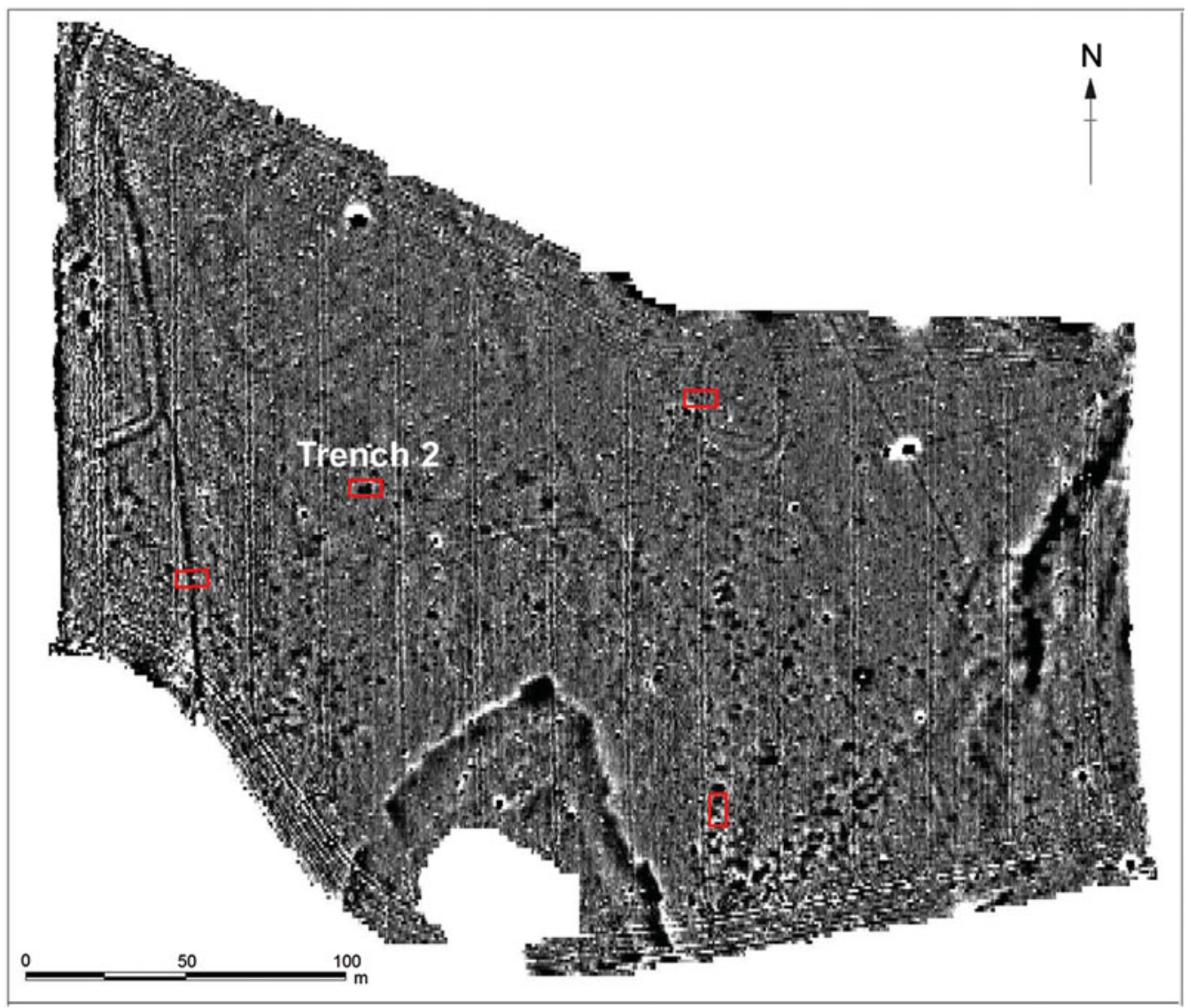

Figure 4. Magnetometry at RLM 044, showing also the location of evaluation trenches (red).

asl, above a marked slope down to the floodplain, a prominent position with commanding views up and down the Deben Valley. To the north-east, across the shallow valley of a stream running into the Deben, the land rises to the interfluve. North-east of the stream, evaluation suggests that a high proportion of the macular features identified by geophysics are early-middle Anglo-Saxon Grubenhäuser and pits, extending over at least 8ha (Figures 4 \& 6). This is similar to the spread of Grubenhäuser at settlements such as Mucking and West Heslerton, and, as at such sites, there are almost certainly ground-level timber buildings whose earth-fast foundations, whether post-holes or narrow trenches, are unlikely to be detected by our geophysics (Hamerow 2012: 67-72). Concentrations of fifth- and sixthcentury dress accessories and decorated pottery in the ploughsoil indicate burials, both furnished inhumations and urned cremations, and the presence of cremations has been confirmed by excavation.

South of the stream, further Grubenhäuser may be identified, but not in the numbers or density seen to the north. Here, aerial photography and magnetometry show a palimpsest of ditches and enclosures, and excavation has demonstrated that these include features from (C) Antiquity Publications Ltd, 2016 


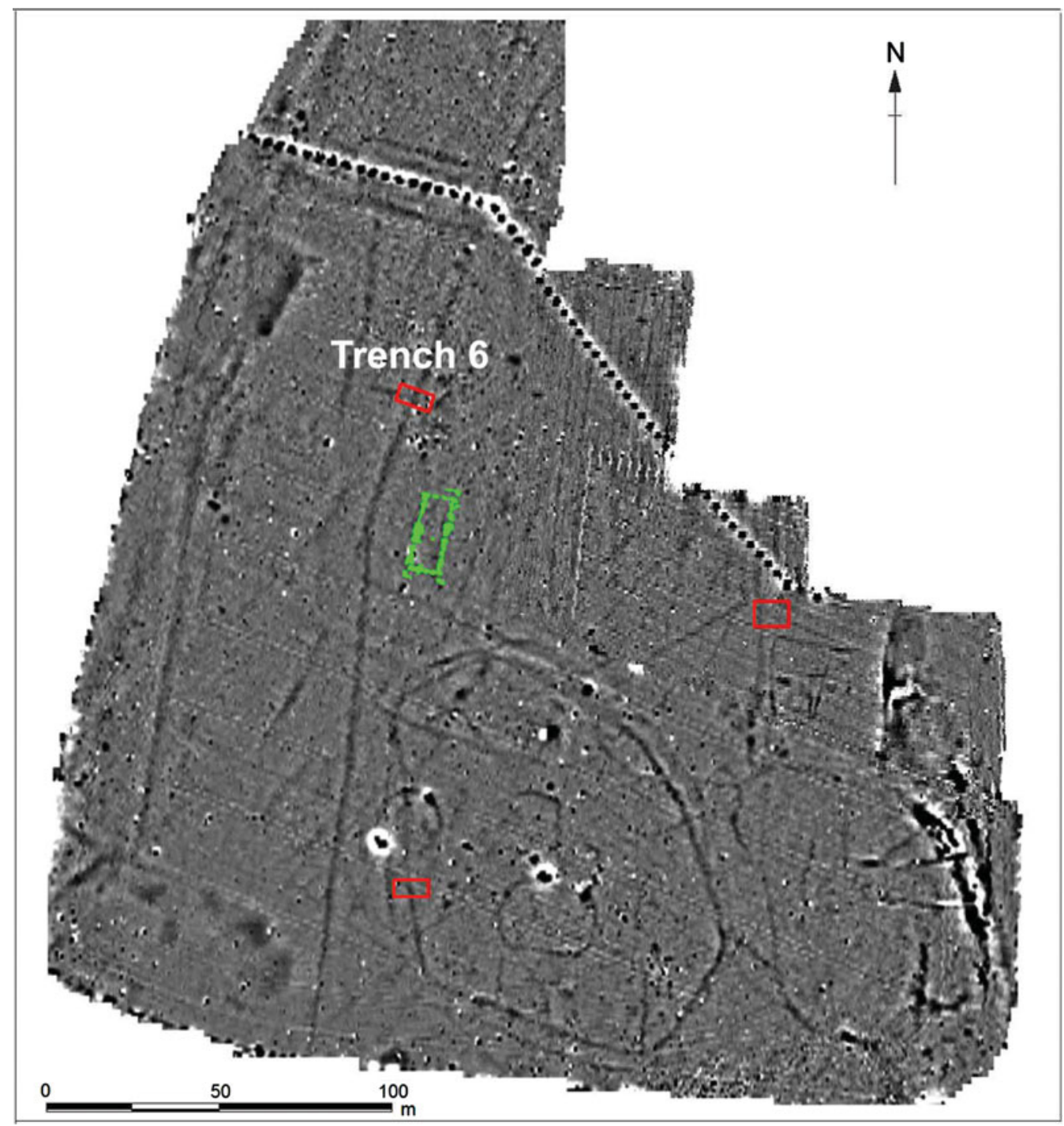

Figure 5. Magnetometry at RLM 013 showing also the cropmark plot of the possible hall (green) and the location of evaluation trenches (red).

the later Iron Age (early first century $\mathrm{AD}$ ) to the medieval period (thirteenth-fourteenth centuries $\mathrm{AD}$ ). A major north-south ditch at the edge of the plateau was shown by evaluation (trench 6) to be early-middle Anglo-Saxon; it was re-cut at least once and may demarcate the western boundary of the settlement (Figures $5 \& 7$ ). To the west, a second linear feature on a parallel alignment at the base of the slope is known from geophysics and aerial photography. Together, they may have delineated a routeway from the south, as well as bounding the settlement, and played a part in controlling the movement of people and livestock. Areas of dark soil derive from buried early-middle Anglo-Saxon cultural deposits, almost certainly

(C) Antiquity Publications Ltd, 2016 


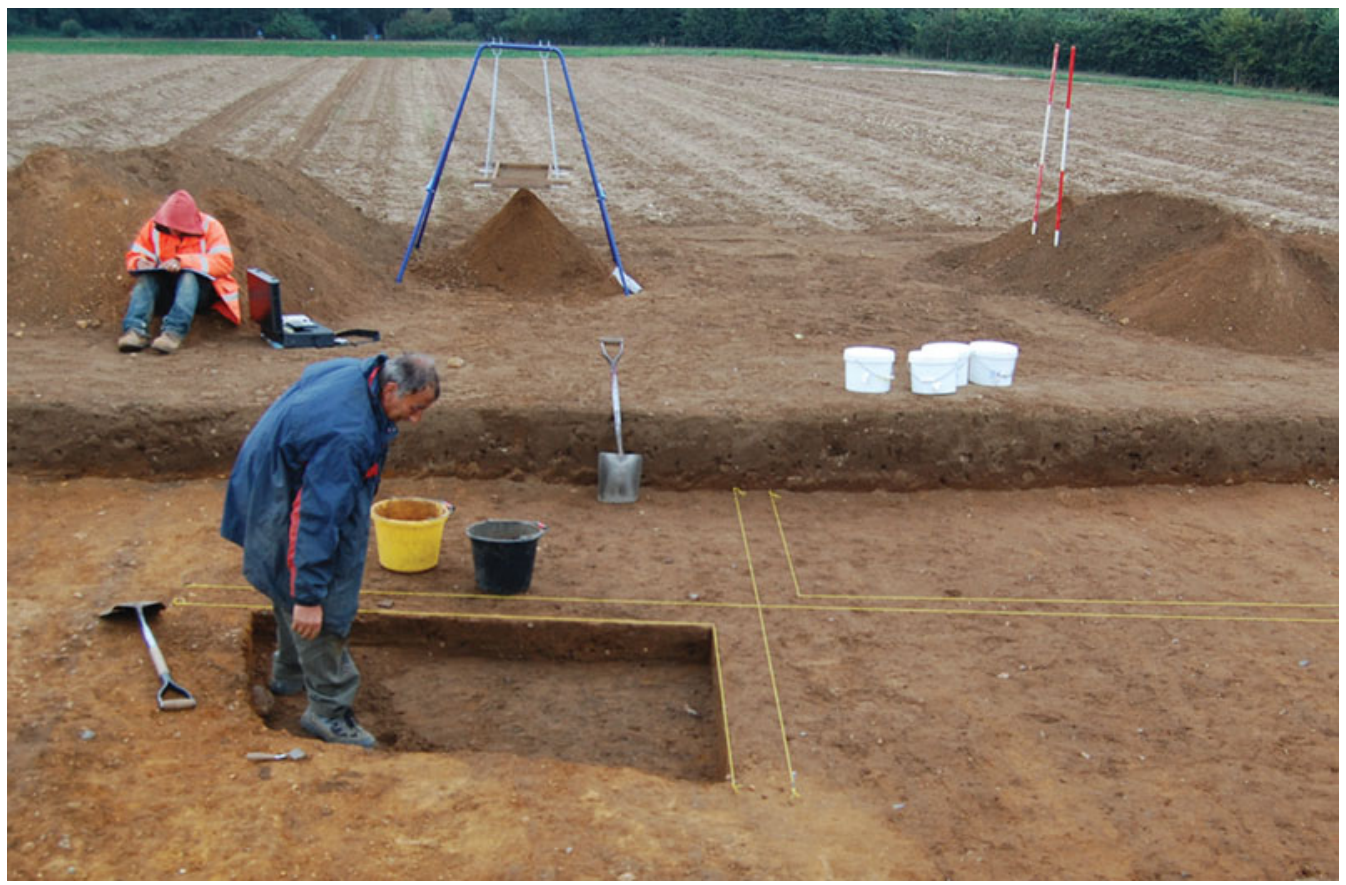

Figure 6. RLM 044: Grubenhaus under excavation in trench 2 (looking south).

midden layers. When encountered elsewhere in East Anglia, as at Brandon and Carlton Colville, such deposits are not far from the major buildings of the settlement (Lucy et al. 2009; Tester et al. 2014). Taken with the concentration of fifth- to eighth-century metal finds - which include gold and gold-and-garnet items of very high quality - and the local micro-topography, this would suggest that any high-status residence was in this area. The identification of a possible major timber building in the immediate vicinity may lend further weight to this model. An Anglo-Saxon building of this size and configuration would normally be attributed to a high-status milieu of the later sixth-eighth centuries (Hamerow 2012: 22-24; 102-109), which would be consistent with the pottery and metal finds. There is no other direct evidence for ground-level timber buildings, but, as noted above, any that did not have large foundation features are unlikely to have been detected by remote sensing. To the south is a cluster of finds indicative of non-ferrous metalworking, and it is very probable that there was a workshop or production area here in the sixth and seventh centuries.

There is a significant late Roman element to the Rendlesham assemblage, untypical of eastern Suffolk, including the latest coinage to reach Britain, and military or official belt fittings. This suggests an official establishment from the later fourth century (Moorhead \& Walton 2014), and the presence of clipped siliquae might indicate the exercise of authority into the fifth century (Guest 2005: 110-15; Abdy 2006). There is evidence for what would conventionally be considered a culturally Germanic presence, with a high-status element, from the second quarter or middle of the fifth century. This may indicate that there was

(C) Antiquity Publications Ltd, 2016 


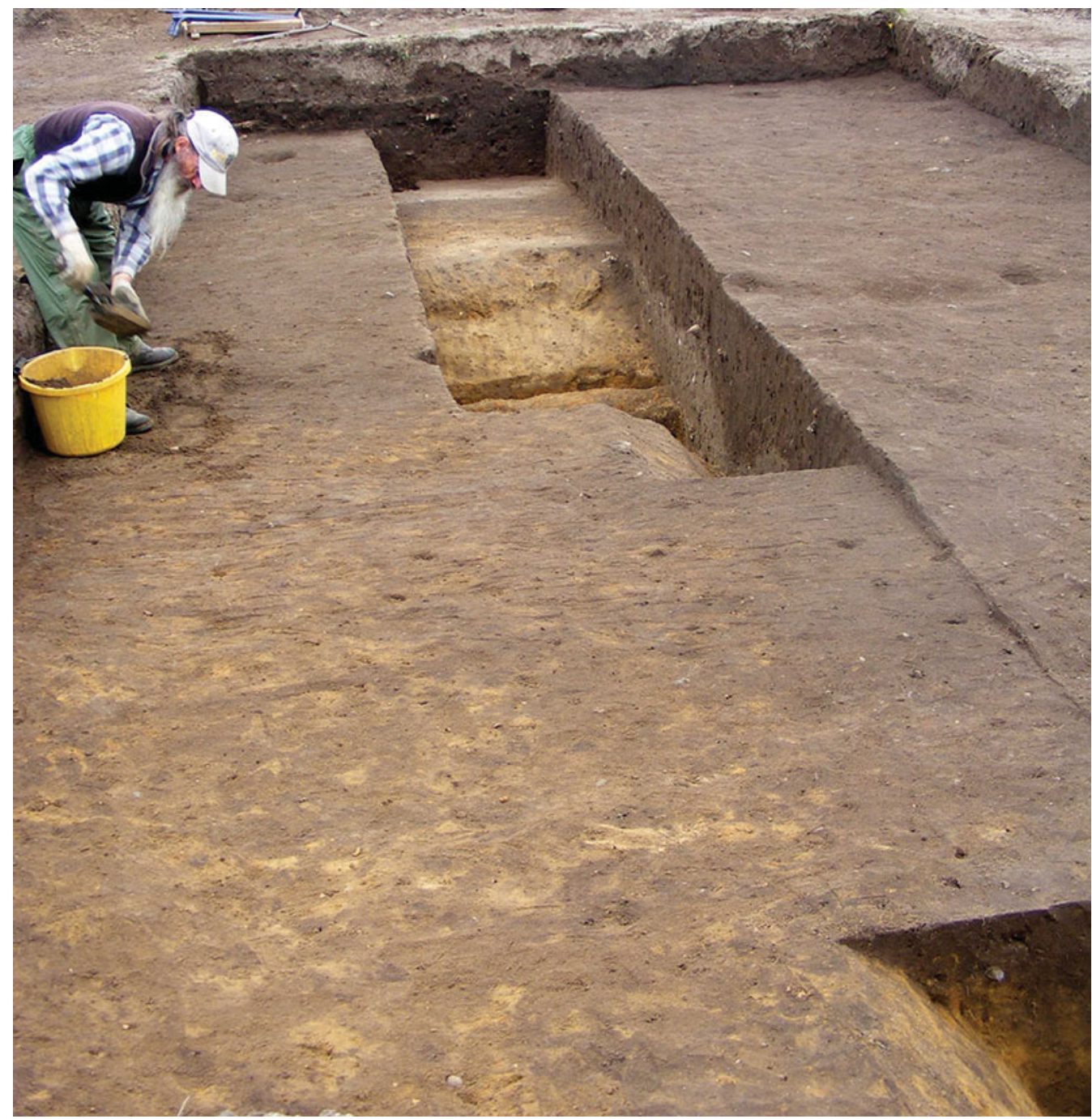

Figure 7. RLM 013: trench 6 under excavation showing the dark midden layers and similar ditch fills (looking east).

no break in activity from the later fourth century, and that the settlement's exceptional character in the sixth-eighth centuries was rooted in its earlier status under the late Roman Empire.

The distribution of finds suggests activity across the entire 50ha throughout the fiftheighth centuries, but it is probable that there were changes in focus and density over time. The site was at the peak of its importance from the early-middle sixth century until the second quarter of the eighth, during which time it was of an extent and material wealth currently difficult to parallel in the contemporary settlement record in England. There appears to have been a change of character and status, and a contraction of the settlement area, from the second quarter or middle of the eighth century, after which the material

(C) Antiquity Publications Ltd, 2016 
culture signature is unremarkable when compared to other contemporary rural sites in the region. There is, however, no evidence for a break in occupation: there were changes in character and spatial configuration, but settlement continued in the immediate vicinity to the eleventh century, and thereafter to the present day. This was a favoured location in the landscape, and the major complex of the sixth-eighth centuries was an episode in a much longer-term sequence of settlement and activity.

In addition to being sited so as to see and be seen by anyone approaching along the river valley, the high-status area is on a slight rise when viewed from the east, and is inter-visible with the settlement and cemetery areas to the north-east. This is a hanging promontory, albeit in a subdued landscape, a class of location identified by Baker and Brookes (2013) as associated with regionally significant assembly places. If the cropmark identification of a hall is correct, then it is probable that there were other major buildings nearby, and it would be possible to argue that this represents the climax of physical investment in the site. The adjacent location of the medieval church, and its unusual dedication to St Gregory the Great, may suggest that it is on or near the site of a much earlier foundation (Scarfe 1987: 90, 103; Hoggett 2010: 154-55). One possible model for Rendlesham in the later seventh and early eighth centuries would therefore be a complex comprising a hall and associated structures, a church, and an agricultural and service settlement to the north and east. As discussed below, however, a link between the church and the seventh- and eighth-century archaeology cannot simply be assumed.

\section{Economic complexity and social diversity}

Sampling the midden deposits has given insights into aspects of provisioning and consumption, and the wider role of animals (Scull 2014). Only a small sample was excavated (around $5 \mathrm{~m}^{3}$ of stratified deposits), but a large quantity of animal bone was recovered $(\mathrm{NISP}=8099)$, representing butchery, food waste and the disposal of other carcasses. The food assemblage is dominated by cattle, pig and sheep, with a high proportion of very young animals selected for consumption. There is evidence for the use of mature bovids for traction, and for periodontal disease associated with pressure on grazing arising from intensive livestock rearing. There are also remains of raptors, horses and large well-fed dogs, which may be indicative of hawking, riding and hunting. Caution must be exercised when interpreting a small sample, but these findings would be consistent with an establishment directly engaged in farming livestock, or in the receipt of livestock as tribute, rent or food renders, or, more probably, both. Meat consumption on a large scale and animals plausibly associated with high-status activities point to an elite element among the population.

Evidence for non-ferrous metalworking in the sixth and seventh centuries includes scrap metal (gold, silver and copper alloy) for reuse; lead models for making moulds; globules and other melted metal spilled during casting; casting sprues; and unfinished items discarded after casting (Figure 8). Precious metal scrap and melt, the lead model for a sword-ring, and an unfinished belt or harness mount in Style II all suggest manufacture for higherstatus patrons, but plain copper-alloy dress pins, buckles and bag catches also point to more everyday production. The precise scale and organisation of metalworking, and the social position of craft workers, remain open questions, but finished and unfinished items

(C) Antiquity Publications Ltd, 2016 

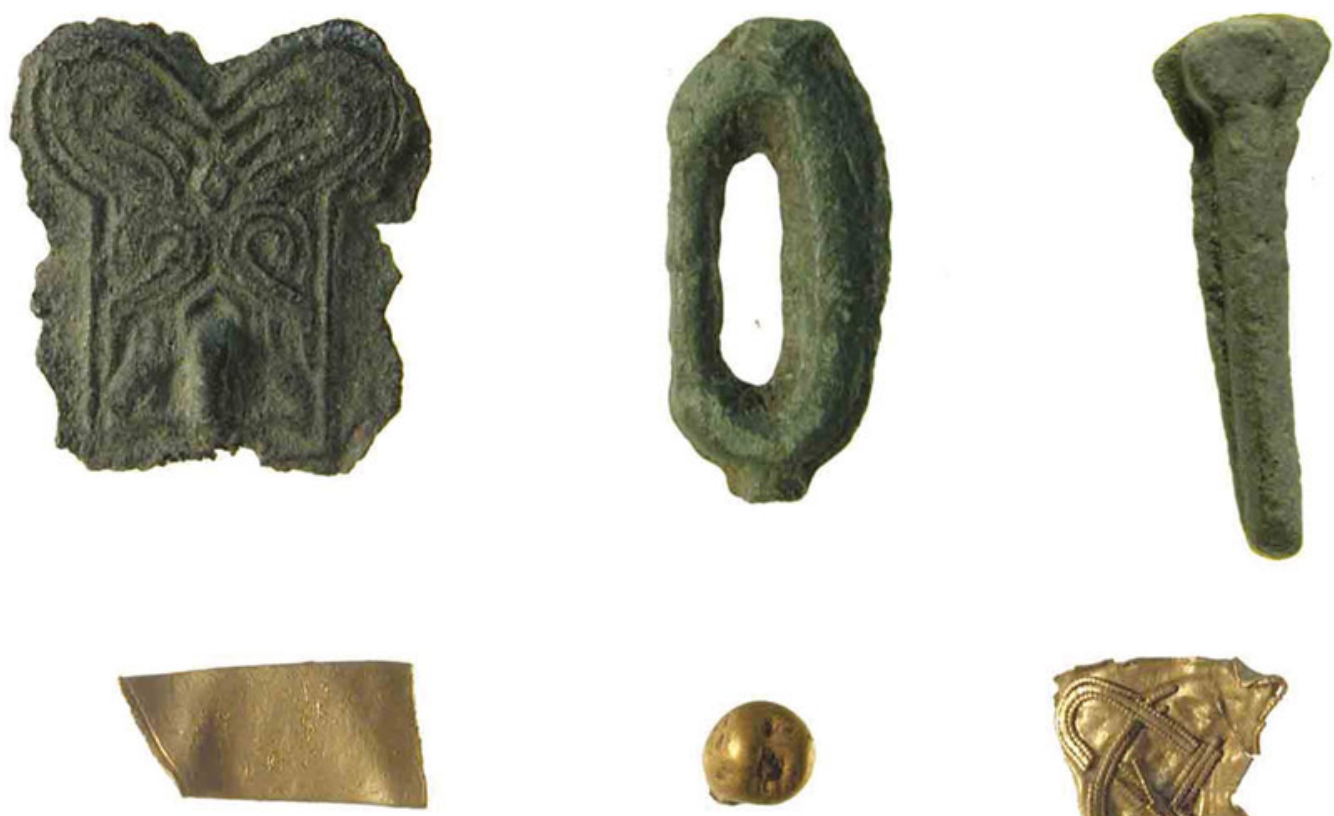

\section{$20 \mathrm{~mm}$}

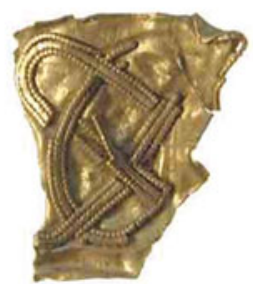

Figure 8. Metal-working evidence: top from left, unfinished copper-alloy objects (mount, buckle and pin); bottom from left, gold sheet offcut, gold droplet and fragment of gold jewellery probably broken up for recycling.

of the same type indicate that some items used and worn by people at Rendlesham were made there, and the relatively large numbers of bag-catches, an item that is known but not common in contemporary burials, may suggest production here for a population wider than the permanent inhabitants of the settlement.

The presence of brooch types that are rare in England and best paralleled in Frankish Gaul suggests a community with inter-regional social and cultural contacts from the early to middle sixth century. Non-local material of the later sixth and seventh centuries includes Frankish gold coinage, elements of hanging-bowls from western or northern Britain, and fragments of Byzantine copper-alloy vessels from the eastern Mediterranean. These would conventionally be seen as acquired indirectly through elite-level gift exchange (Richards 1983; Harris 2003), but finds from Rendlesham include eight Byzantine copper coins of the late sixth and earlier seventh centuries (folles and half-folles of Justin II to Heraclius) whose provenance from a contemporary high-status site adds to the growing body of evidence that Byzantine coinage was travelling to England at this time (Moorhead 2009; Morrison 2014). If found in a western British context, they would be considered indicative of direct mercantile contacts with the Mediterranean, and we see no reason to think otherwise here. We are not suggesting that these low-value coins circulated as currency in England, but rather that they were lost by people for whom they had a monetary value and so are a proxy 


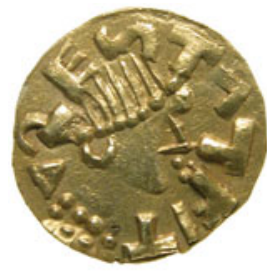

A
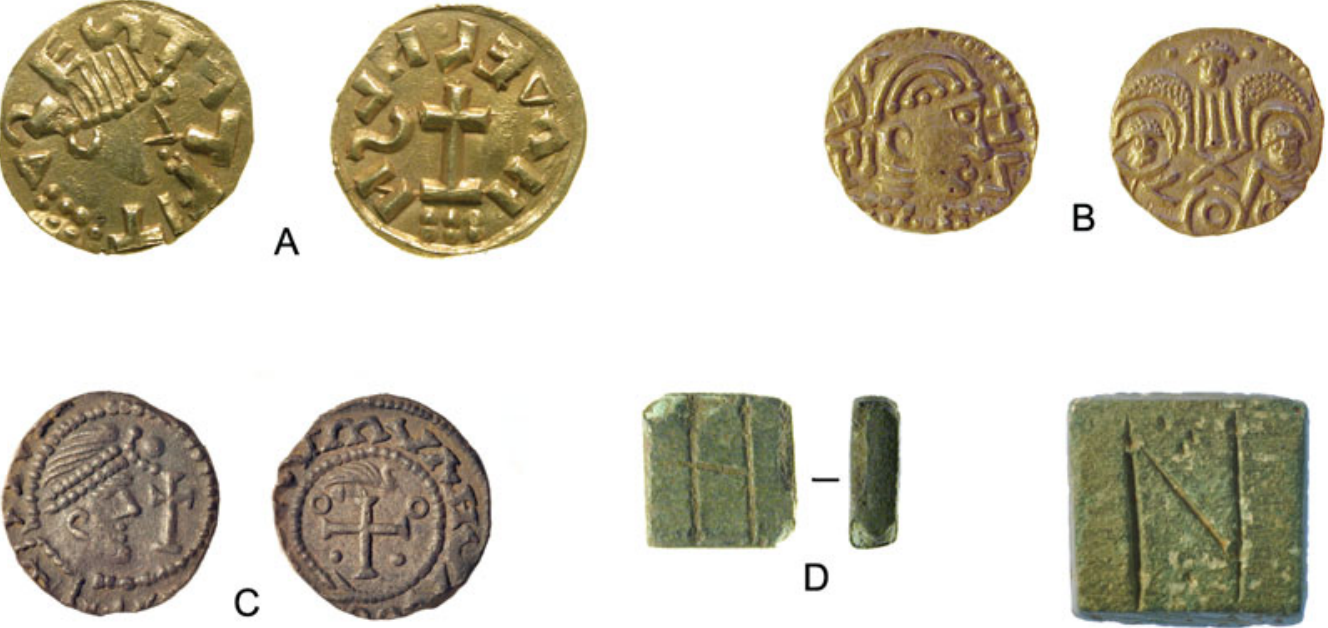

$\mathrm{E}$

Figure 9. Coins and coin weights: A) Merovingian tremissis, Dorestat/Madelinus type struck at Dorestad; B) Anglo-Saxon gold shilling, Sutherland II.S.ii: Two Emperors (21); C) silver sceat, Primary Series Bib; D) copper-alloy coin weight inscribed $H$ (=1 tremissis); E) copper-alloy coin weight inscribed $N$ (=1 solidus).

for individuals from Byzantine territory and a residue of trade in high-value goods. They suggest that Byzantine imports were arriving in south-east England through mercantile channels as well as socially embedded exchange.

Rendlesham has yielded an exceptionally large assemblage of sixth- to eighth-century coins (Figure 9). Excluding those adapted as jewellery, the database records 25 early gold coins of $c$. AD 580-675 (the majority Merovingian tremisses but including six English gold shillings) and 168 silver pennies (sceattas) of $c$. AD 675-750. There are some broad pennies of the mid eighth century and later, but when compared to regional and national patterns of coin loss, Rendlesham shows an unusual degree of early activity during the gold period, a peak around $\mathrm{AD} 700$ and a marked early fall-off after $c$. AD 720. Both gold coins and sceattas are found across the settlement area with no significant clustering and very similar distributions; they cannot be explained as hoards and must therefore represent loss through transactions. Rendlesham was a place to which coin flowed disproportionately from the later sixth to the earlier eighth centuries, and it would appear that the gold coinage was circulating as currency and not just as bullion or raw material for the jeweller. Coin weights marked with contemporary Byzantine denominations, cut coins, blanks and ingots, and a gilded silver forgery of a Merovingian tremissis; all suggest a system in which the gold coins were recognised as units of account that might need to be checked for weight and fineness, but where payments might also be made in equivalent weights of uncoined bullion (Steuer 1987; Scull 1990). The socially restricted circulation of gold currency provides a monetary context for high-value long-distance exchange. It also helps to define the conditions from which the deeper monetisation developed, which is seen in the issue and uptake of silver coinages from the third quarter of the seventh century.

(C) Antiquity Publications Ltd, 2016 


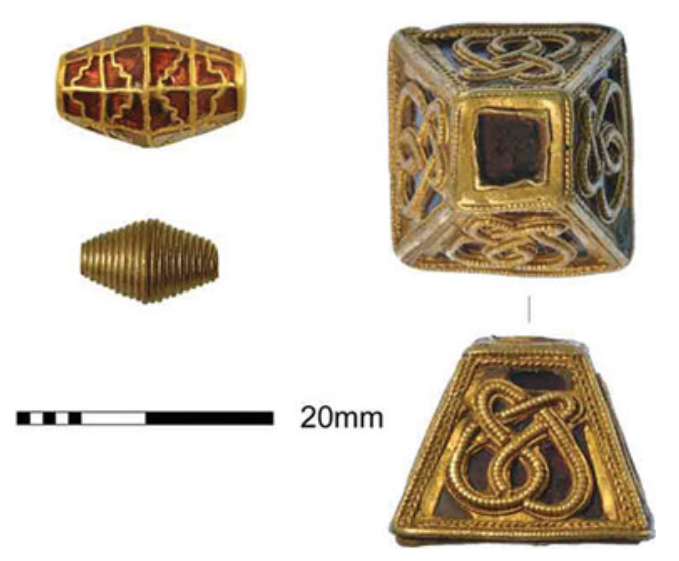

Figure 10. Elite metalwork: gold-and-garnet bead, gold wire bead and gold-and-garnet pyramid-shaped mount from a sword scabbard. emphasise that most items from Rendlesham are unostentatious copper alloy and that the material speaks of a social range.

\section{Interpretation and context}

The archaeology at Rendlesham indicates an extensive polyfocal complex, long-lived but changing and developing over time (Figure 11). The wider scatter of coinage and metalwork probably represents periodic activity as well as a permanent settlement, but even so the complex is very much more extensive than any known contemporary rural settlement.

Our preliminary interpretation of the sixth- to eighth-century complex is that it was a farm, a residence and a tribute centre where the land's wealth was collected and redirected, major administrative payments made, and important social and political events transacted. It can be seen as a permanent centre for agrarian or economic administration, a periodic residence for a peripatetic elite, and a periodic meeting place for military and jurisdictional assemblies. The broader scatter of metalwork finds includes items such as harness and weapon fittings, consistent with a high-status social milieu, which might be explained as the aggregate loss from years of such gatherings. By the sixth century, this place was at the apex of a system of surplus extraction and jurisdiction, and at the centre of the networks of consumption, redistribution and patronage that fuelled elite social and political relationships. Even without Bede's reference, it would be a strong candidate for a seventh-century royal centre.

We believe that coinage was used as currency at Rendlesham from some time in the sixth century. Social and jurisdictional contexts would usually be emphasised for payments in gold, the elite currency of worth and reward, but more commercial transactions are also indicated (cf. Blackburn 2011; Williams 2013). A permanent administrative function, the periodic presence of an elite household, and assemblies of the social elite would be powerful attractions for directed trade, and might over time foster a periodic market or fair. Something was given for Frankish gold and Byzantine imports, and the products of a dominial farming and craft production surplus might be part of the answer. Conversely, the later and lower-value silver coinage is usually seen as indicative of an increasingly monetised

(C) Antiquity Publications Ltd, 2016 


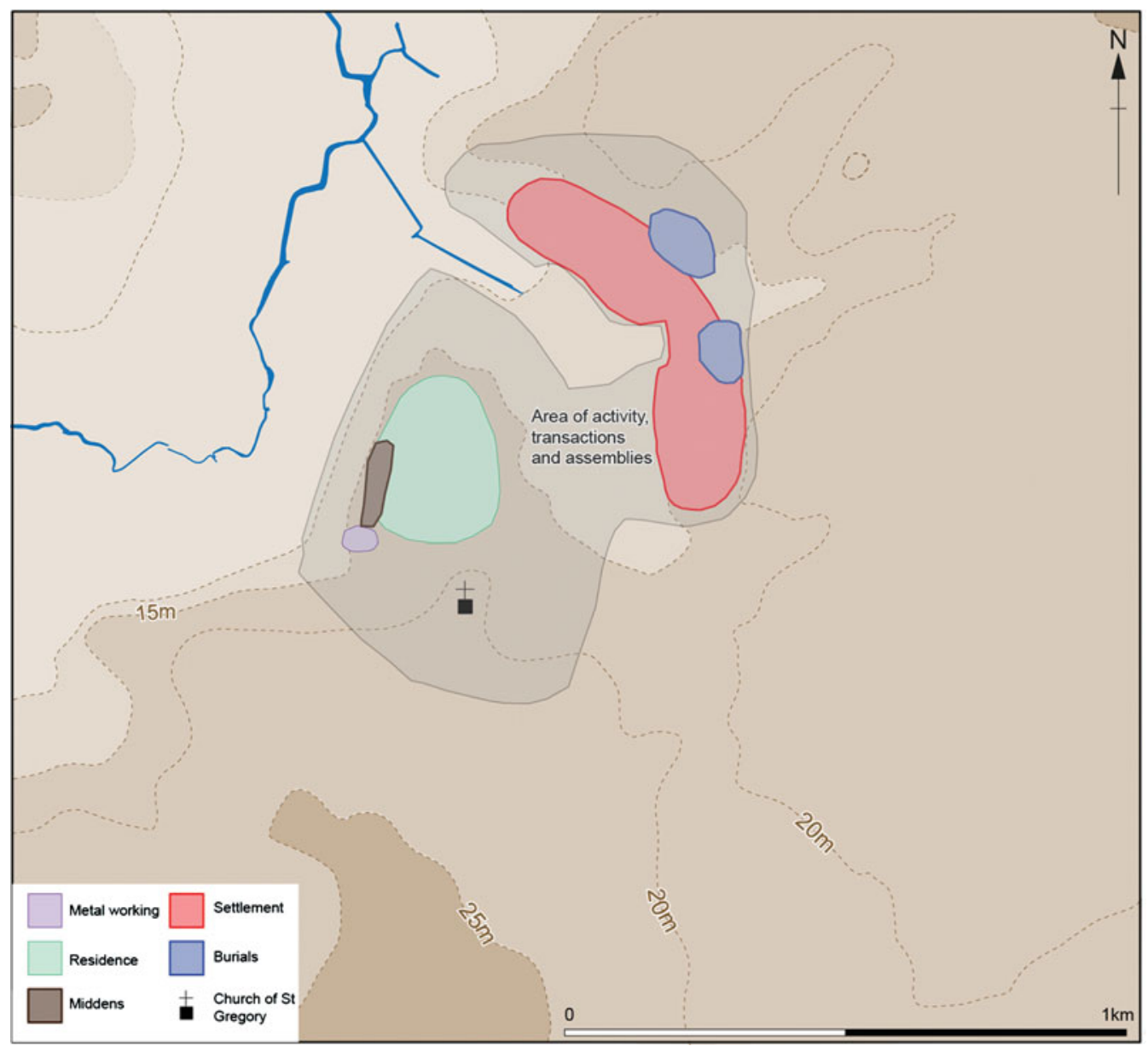

Figure 11. Spatial model of Anglo-Saxon activity in the core area of the survey.

market economy, but we should also envisage its use in jurisdictional and administrative payments (cf. Astill 2011: 503-506; Blackburn 2011).

In the seventh century, the area of activity at Rendlesham appears to have been greater than the contemporary trading settlement (wic or emporium) at Ipswich (Scull 2009: 313-16). The material culture assemblages are, however, very different: Rendlesham has little or no imported pottery, and Ipswich lacks the early coinage, material wealth and elite metalwork that is found at Rendlesham. Coin-rich sites in the hinterlands of the major emporia are usually seen as having a formal market function relating to the commercial redistribution of imported goods (Ulmschneider 2000; Naylor 2004), but at best this can offer only a very partial explanation for Rendlesham. Coddenham, $11 \mathrm{~km}$ north of Ipswich in the Gipping Valley, was in many ways similar to Rendlesham in the sixth to earlier eighth centuries, although apparently less extensive: a materially wealthy settlement with evidence for elite consumption and display, and non-ferrous metalworking (Everett et al. 2003; Newman 2003; Penn 2011). Rather than market sites, these look like magnate residences or estate (C) Antiquity Publications Ltd, 2016 
centres that were integrated into a monetising economy, suggesting that by the late sixth or early seventh centuries, and probably well before, there was a centralising of economic functions and control at some major rural centres. Seventh-century Ipswich may therefore have been less a port than a staging post or foreign traders' enclave, with the real business of trade in high-value goods directed to agents of the social elite at places such as Rendlesham and Coddenham. Both sites show a decline in monetary usage from $c$. AD 720, broadly coinciding with the major expansion of Ipswich as a manufacturing centre and international trading port from $c$. AD 700-720. One factor in the apparent change of character at both Rendlesham and Coddenham may therefore be that the expanding volume of international commerce was increasingly handled at coastal ports, while inland centres became more wholly concerned with the management of the rural economy.

Rendlesham was an important place when the first burials were made at Sutton Hoo and when Bede was writing more than 100 years later. The people who buried their dead at Sutton Hoo probably stayed at Rendlesham, and derived some of their wealth from its dues, and it is possible that some of the objects found at Sutton Hoo were made at Rendlesham. There is always a temptation to tie princely burial to princely residence, and it has been suggested that the three modern parishes of Rendlesham, Eyke and Bromeswell on the east side of the River Deben encapsulate a seventh-century administrative territory with its caput at Bede's vicus regius and an associated dynastic cemetery, later an execution site, on its southern boundary at Sutton Hoo (Warner 1996: 115-19). Elite burial at Sutton Hoo, however, was a relatively brief episode within the much longer lifetime of the Rendlesham settlement, whose residents and magnates must therefore have had other burial places, and even when both were in contemporaneous use, a simple or exclusive one-to-one relationship cannot be assumed. Peripatetic kings or magnates would have had other residences, and elite kindreds may have buried their dead at more than one place according to circumstance. Coddenham would appear to be just such another magnate centre, and there is at least one other comparable contemporary site known from metal-detecting in Suffolk (Scull in press). Other elite Anglo-Saxon burial sites are known to archaeology in east Suffolk at Snape (Filmer-Sankey \& Pestell 2000) and Carlton Colville (Newman 1996), and later tradition identifies Blythburgh as the burial place of King Anna, killed AD 653/654 (L.E. i. 7; Blake 1962). Patterns of settlement and burial were complex and dynamic (Chester-Kadwell 2009; Hamerow 2012; Semple 2013: 13-62), and there is both accumulating evidence for other sites along the Deben Valley between Rendlesham and Sutton Hoo (Figure 12), and evidence suggesting seventh-century inhumations at Rendlesham itself. While recognising the overwhelming probability that Rendlesham and Sutton Hoo were linked in the social theatre of rulership and its inscription on the landscape in the first half of the seventh century, we should be wary of over-privileging the pairing to the extent that it is allowed to obscure other geographies and relationships, earlier, contemporaneous and later.

It is frequently assumed that Rendlesham was the main 'palace' of the East Anglian rulers, and that it was here that King Redwald maintained altars to both Christ and devils; thus, for example, Bruce-Mitford's model of the vicus regius, which is based upon the Heorot of Beowulf, Yeavering and Old Uppsala (Bruce-Mitford 1974: 94-95). This is, however, speculative (Williamson 2008: 96-101). Bede (H.E. ii. 15; Colgrave \& Mynors 1969) does not identify Rendlesham as the site of Redwald's shrine, and relative proximity to Sutton 


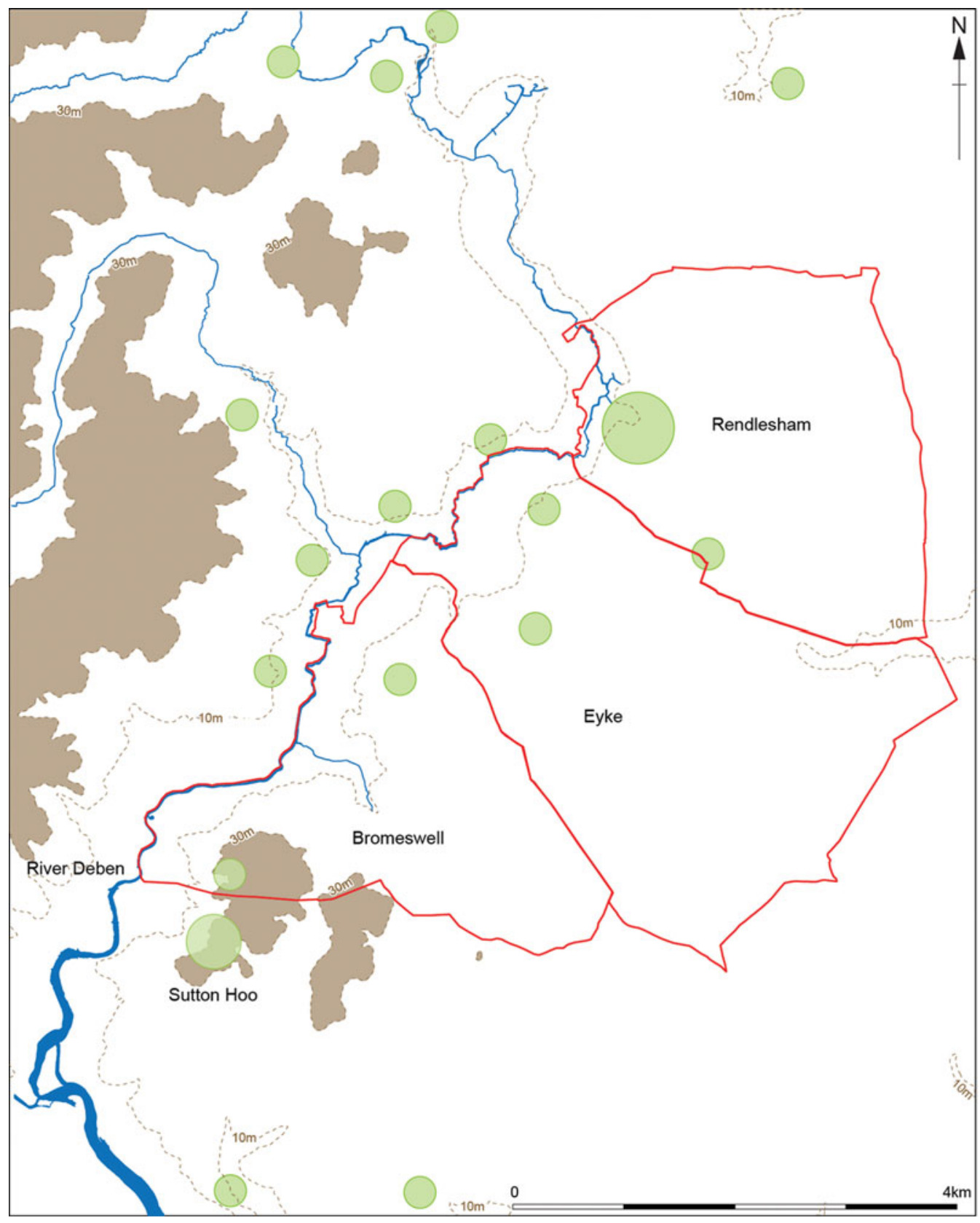

Figure 12. Map of the Deben Valley around Rendlesham and Sutton Hoo showing early to middle Anglo-Saxon sites and finds (green spots) and the parishes of Bromeswell, Eyke and Rendlesham (red outline) (contours at 10m and 30m OD).

(C) Antiquity Publications Ltd, 2016 
Hoo cannot necessarily be taken as evidence for an exclusive primary status. Inferences linking the present church to the baptism of Swithhelm are similarly fragile. Bede gives no further details other than that Swithhelm was baptised by Cedd, and that King Aethelwold of the East Angles was his sponsor. The baptism may have been in a church, which may or may not have been successively rebuilt on or near the site of the current building, but Swithhelm may have been baptised in the open air, perhaps in the nearby River Deben just as Paulinus baptised converts in the River Glen at Yeavering and the River Swale at Catterick (H.E. ii. 14; Colgrave \& Mynors 1969). The church of St Gregory might have a close and direct connection to Swithhelm's baptism and the seventh-century elite settlement, but it might also be a later foundation.

It is not certain exactly what Bede meant when he termed Rendlesham a vicus regius, nor whether he intended it to apply to the 660s or 720 s, or both, and there are other difficulties relating seventh- and eighth-century settlement vocabulary to the archaeological record. Campbell (1986: 108-11) argued that Bede used vicus and villa synonymously to denote the central place of an extensive estate or region, and archaeology has identified arrays of large timber halls that can be identified as such places (Hamerow 2012: 102-109). Survey at Rendlesham and recent excavations at Lyminge (Thomas 2013) suggest, however, greater complexity. Kings and magnates may have owned and had interests in a range of places with different social, economic and administrative characteristics that changed over time. It is therefore possible, as Campbell (1986: 108) noted, that Bede's use of the terms vicus regius and villa regalis might sometimes convey awareness of a genuine distinction-perhaps that to be drawn between an extensive settlement embodying a range of rights and obligations under the umbrella of lordship (vicus), and the buildings of a discrete elite residence and administrative establishment (villa). If so, then in theory a villa might stand alone as the caput of a region or estate, or be co-located with or within a vicus.

\section{Conclusions}

The identification of a long-lived central place complex is something new in the archaeology of early-middle Anglo-Saxon England. Thus, Rendlesham invites comparison with sites in Denmark and southern Sweden such as Gudme and Uppåkra (Nielsen et al. 1994; Hårdh 2002; Larsson 2004; Jørgensen 2011; Stidsing et al. 2014), yet it also needs to be seen against the economic and political geography of the near Channel and North Sea coasts, in particular the emergence of polyfocal central places in north Frankia (Loveluck 2013: 149-50). It therefore begins to align south-east England with much broader contemporary trajectories of economic and socio-political development both within and without the former provinces of the Roman Empire. Although Rendlesham is currently unique in the archaeological record of England in its extent, wealth, longevity and complexity, it is important to recognise that other contemporary high-status sites have not been investigated on this scale or with the same array of extensive approaches, and that some may prove to be more closely comparable. At Sutton Courtenay/Drayton in Oxfordshire, for example, an area of Grubenhäuser and timber buildings is known some $300-400 \mathrm{~m}$ north of the high-status hall complex, and limited metal-detecting suggests an activity profile similar to Rendlesham (Hamerow et al. 2007; Brennan \& Hamerow 2015).

(C) Antiquity Publications Ltd, 2016 
It is highly probable that archaeology at Rendlesham has identified the site of the vicus regius mentioned by Bede, and its antecedents and successors. The settlement shows an unexpectedly early and sophisticated degree of monetary circulation and integration with long-distance exchange networks, which in turn implies enduring and robust economic and administrative geographies underpinning social hierarchy and elite consumption. It may also show signs of an early centralising of craft production. Its importance for at least 200 years before the early-middle eighth century runs counter to the view that secular elite sites of this period in England were necessarily transient or short-lived, and that organisational or administrative stability was introduced by and was exclusive to the Anglo-Saxon church (Blair 2005: 247-86). This in turn has implications for the degrees of socio-economic complexity underpinning the dynamics of allegiance and lordship that governed the emergence of regional hegemonies- the Anglo-Saxon kingdoms-in the sixth and seventh centuries. The 'long eighth century' is widely seen as the first major threshold of complexity in the long-term transformations of production, exchange and social relations in post-Roman north-west Europe (Hansen \& Wickham 2000), but we should be wary of under-estimating the sophistication of earlier social and economic configurations in south-east England.

\section{Acknowledgements}

The Rendlesham project is managed by Suffolk County Council Archaeological Service with the support of the landowners, Sir Michael and Lady Caroline Bunbury, and Colchester and Ipswich Museum Service. It is funded by the Sutton Hoo Society, Historic England, the Suffolk Institute of Archaeology and History, the Society of Antiquaries of London, the Society for Medieval Archaeology and the Royal Archaeological Institute, and generously supported by the Portable Antiquities Scheme and the Fitzwilliam Museum, Cambridge. The metal-detector survey was undertaken by Rob Atfield, Roy Damant, Terry Marsh and Alan Smith. We have drawn on the work of many colleagues for this preliminary report, in particular geophysics by Helen Woodhouse and Neil Paveley (Woodhouse Consultancy), study of the coinage by Martin Allen (Fitzwilliam Museum), Sam Moorhead (British Museum) and Andrew Woods (Yorkshire Museum), and analysis of the animal bone by Charlotte Scull (University of Reading), but responsibility for opinions and any errors rests with the authors.

\section{References}

ABDY, R. 2006. After Patching: imported and recycled coinage in fifth- and sixth-century Britain, in B. Cook \& G. Williams (ed.) Coinage and history in the North Sea world c. AD 500-1250. Essays in honour of Marion Archibald: 75-98. Leiden: Brill.

AstiLL, G. 2011. Overview: trade, exchange and urbanization, in H. Hamerow, D. Hinton \& S. Crawford (ed.) The Oxford handbook of Anglo-Saxon archaeology: 503-14. Oxford: Oxford University Press. http://dx.doi.org/10.1093/ oxfordhb/9780199212149.013.0026

BAKER, J. \& S. BROOKES. 2013. Monumentalising the political landscape: a special class of Anglo-Saxon assembly site. The Antiquaries Journal 93: 147-62. http://dx.doi.org/10.1017/S0003581512001333

Behr, C. \& T. Pestell. 2014. The bracteate hoard from Binham - an early Anglo-Saxon central place. Medieval Archaeology 58: 44-77. http:

//dx.doi.org/10.1179/0076609714Z.00000000031
BlaCKBURn, M. 2011. Coinage in its archaeological context, in H. Hamerow, D. Hinton \& S. Crawford (ed.) The Oxford handbook of Anglo-Saxon archaeology: 580-99. Oxford: Oxford University Press. http://dx.doi.org/10.1093/ oxfordhb/9780199212149.013.0030

BLAKE, E.O. (ed.). 1962. Liber Eliensis. London: Camden Society.

BLAIR, J. 2005. The church in Anglo-Saxon society. Oxford: Oxford University Press.

Brennan, N. \& H. Hamerow. 2015. An Anglo-Saxon great hall complex at Sutton Courtenay/Drayton, Oxfordshire: a royal centre of early Wessex? The Archaeological Journal 172: 325-50. http: //dx.doi.org/10.1080/00665983.2015.1010369

BRUCE-Mitford, R. 1948. Saxon Rendlesham. Proceedings of the Suffolk Institute of Archaeology and Natural History 24: 228-51.

(C) Antiquity Publications Ltd, 2016 


\section{Social and economic complexity in early medieval England}

- 1974. Saxon Rendlesham, in R. Bruce-Mitford, Aspects of Anglo-Saxon archaeology: Sutton Hoo and other discoveries: 73-113. London: Gollancz.

CAmpBell, J. 1986. Bede's words for places, in J. Campbell, Essays in Anglo-Saxon history: 99-119. London: Hambledon.

Carver, M.O.H. 2005. Sutton Hoo: a seventh-century princely burial ground and its context (Reports of the Research Committee of the Society of Antiquaries of London 69). London: British Museum.

CHeSTER-KaDWELl, M. 2009. Early Anglo-Saxon communities in the landscape of Norfolk (British Archaeological Reports British series 481). Oxford: Archaeopress.

Clarke, R.R. 1960. East Anglia. London: Thames \& Hudson.

Colgrave, B. \& R.A.B. Mynors (ed.). 1969. Bede's ecclesiastical history of the English people. Oxford: Clarendon.

Dunster, J., D. Dungworth \& A. Lowerre. 2012. Rendlesham, Suffolk. Characterising metalworking through a geochemical survey of ploughsoil (Research Report Series 30-2012). Portsmouth: English Heritage.

Everett, L., S. Anderson, K. Powell \& I. Riddler. 2003. Vicarage Farm, Coddenham CDD 022. An archaeological evaluation. Suffolk County Council Archaeological Service Report 03/66.

Filmer-SAnKey, W. \& T. Pestell. 2000. Snape Anglo-Saxon cemetery. Excavations and survey 1824-1992 (East Anglian Archaeology Report 95). Ipswich: Suffolk County Council.

Guest, P. 2005. The late Roman gold and silver coins from the Hoxne treasure. London: British Museum.

HaMerow, H. 2012. Rural settlements and society in Anglo-Saxon England. Oxford: Oxford University Press. http://dx.doi.org/10.1093/acprof: oso/9780199203253.001.0001

Hamerow, H., C. Hayden \& G. Hey. 2007. Anglo-Saxon and earlier settlement near Drayton Road, Sutton Courtenay, Berkshire. The Archaeological Journal 164: 109-96. http: //dx.doi.org/10.1080/00665983.2007.11020708

Hansen, I. \& C. WiCKHAM (ed.). 2000. The long eighth century. Production, distribution and demand. Leiden: Brill.

HÅRDH, B. 2002. Uppåkra in the Migration and Merovingian periods, in B. Hårdh \& L. Larsson (ed.) Central places in the Migration and Merovingian periods (Uppåkrastudier 10): 41-54. Stockholm: Almqvist \& Wiksell.

Harris, A. 2003. Byzantium, Britain and the West. The archaeology of cultural identity AD 400-650. Stroud: Tempus.

HoggetT, R. 2010. The archaeology of the East Anglian conversion. Woodbridge: Boydell.
JørGENSEN, L. 2011. Gudme-Lundeborg on Funen as a model for northern Europe? in O. Grimm \&

A. Pesch (ed.) The Gudme/Gudhem phenomenon (Schriften des archäologisches Landesmuseums Ergänzungsreihe 6): 77-89. Neumunster: Wachholtz.

LARSSON, L. (ed.). 2004. Continuity for centuries: a ceremonial building and its context at Uppåkr, southern Sweden (Uppåkrastudier 10). Lund: University of Lund.

LOVELUCK, C. 2013. Northwest Europe in the early Middle Ages, c. AD 600-1150. A comparative archaeology. Cambridge: Cambridge University Press. http://dx.doi.org/10.1017/CBO9781139794725

Lucy, S., J. Tipper \& A. Dickens. 2009. The Anglo-Saxon settlement and cemetery at Bloodmoor Hill, Carlton Colville, Suffolk (East Anglian Archaeology Report 131). Cambridge: Cambridge Archaeological Unit.

Martin, E., J. Plouviez \& C. Pendleton. 1983. Archaeology in Suffolk 1982. Proceedings of the Suffolk Institute of Archaeology and History 35: 229-35.

Moorhead, S. 2009. Early Byzantine copper coins found in Britain: a review in light of new finds recorded with the Portable Antiquities Scheme, in O. Tekin (ed.) Ancient history, numismatics and epigraphy in the Mediterranean world. Studies in honour of Clemens E. Bosch and Sabahat Atlan and in honour of Nezahat Baydur: 263-74. Istanbul: Ege.

Moorhead, S. \& P. Walton. 2014. Coinage at the end of Roman Britain, in F.K. Haarer, R. Collins, K. Fitzpatrick-Matthews, S. Moorhead, D. Petts \& P. Walton (ed.) AD 410: the history and archaeology of Late and Post-Roman Britain: 99-116.

Morrison, C. 2014. Byzantine coins in early medieval Britain: a Byzantinist's assessment, in R. Naismith, M. Allen \& E. Screen (ed.) Early medieval monetary history: studies in memory of Mark Blackburn: 207-42. Farnham: Ashgate.

NAYLOR, J. 2004. An archaeology of trade in Middle Saxon England (British Archaeological Reports British series 376). Oxford: Archaeopress.

Newman, J. 1992. Late Roman and Anglo-Saxon settlement patterns in the Sandlings of Suffolk, in M. Carver (ed.) The age of Sutton Hoo: the seventh century in north-western Europe: 25-38. Woodbridge: Boydell.

- 1996. New light on old finds_-Bloodmoor Hill, Gisleham, Suffolk. Anglo-Saxon Studies in Archaeology and History 9: 75-79.

- 2003. Exceptional finds, exceptional sites? Barham and Coddenham, Suffolk, in T. Pestell \& K. Ulmschneider (ed.) Markets in early medieval Europe: trading and 'productive' sites, 650-850: 97-109. Macclesfield: Windgather. 
Nielsen, P., K. Randsborg \& H. Thrane (ed.). 1994. The archaeology of Gudme and Lundeborg.

Copenhagen: Akademisk Forlag \& Universitetsforlager i København.

Penn, K. 2011. The Anglo-Saxon cemetery at Shrubland Hall quarry, Coddenham, Suffolk (East Anglian Archaeology Report 139). Bury St Edmunds: Suffolk County Council Archaeological Service.

RiCHARDS, P. 1983. Byzantine bronze vessels in Britain and Europe: the origins of Anglo-Saxon trade. Unpublished PhD dissertation, Cambridge University.

SCARFE, N. 1987. The Suffolk landscape. Bury St Edmunds: Alastair.

SCULL, C.J. 1990. Scales and weights in early Anglo-Saxon England. The Archaeological Journal 147: 183-215. http: //dx.doi.org/10.1080/00665983.1990.11077944

- 2009. Early medieval (late $5^{\text {th }}$-early $8^{\text {th }}$ centuries AD) cemeteries at Boss Hall and Buttermarket, Ipswich, Suffolk (Society for Medieval Archaeology Monograph 27). London: Society for Medieval Archaeology.

- In press. Archaeology and geographies of jurisdiction: evidence from south-east Suffolk in the seventh century, in J. Caroll, A. Reynolds \& B. Yorke (ed.) Power and place in later Roman and early medieval Europe. London: British Academy.

SCULL, C.J.A. 2014. Beasts and feasts at Anglo-Saxon Rendlesham. Unpublished MRes dissertation, University of Reading.

SEMPLE, S. 2013. Perceptions of the prehistoric in Anglo-Saxon England: religion, ritual and rulership in the landscape. Oxford: Oxford University Press. http://dx.doi.org/10.1093/acprof: oso/9780199683109.001.0001
STEUER, H. 1987. Gewichtsgeldwirtschaft im frühgeschichtlichen Europa, in K. Düwel, H. Jankuhn, H. Siems \& D. Timpe (ed.) Untersuchungen zu Handel und Verkehr der vor-und frühgeschichtlichen Zeit in Mittel und Nordeuropa 4: der Handel des frühen Mittelalters: 405-527. Göttingen: Vandehoeck \& Ruprecht.

Stidsing, E., K. Høilund Nielsen \& R. Fiedel (ed.). 2014. Wealth and complexity: economically specialised sites in late Iron Age Denmark. Århus: Århus University Press.

Tester, A., S. Anderson, I. Riddler \& R. CARr. 2014. Staunch Meadow, Brandon: a high-status Middle Saxon settlement on the fen edge (East Anglian Archaeology Report 151). Bury St Edmunds: Suffolk County Council Archaeological Service.

Thomas, G. 2013. Life before the minster: the social dynamics of monastic foundation at Anglo-Saxon Lyminge, Kent. The Antiquaries Journal 93: 109-45. http://dx.doi.org/10.1017/S0003581513000206

UlMSCHNEIDER, K. 2000. Markets, minsters and metal-detectors: the archaeology of Middle Saxon Lincolnshire and Hampshire compared (British Archaeological Reports British series 307). Oxford: Archaeopress.

WARNER, P. 1996. The origins of Suffolk. Manchester: Manchester University Press.

WiLliams, G. 2013. The circulation, minting and use of coins in East Anglia, c. AD 580-675, in D. Bates \& R. Liddiard (ed.) East Anglia and its North Sea world in the Middle Ages: 120-36. Woodbridge: Boydell.

Williamson, T. 2008. Sutton Hoo and its landscape: the context of monuments. Oxford: Oxbow.

YounG, A. 1797. General view of the agriculture of the county of Suffolk. London: Board of Agriculture.

Received: 12 August 2015; Accepted: 12 November 2015; Revised: 15 December 2015

C) Antiquity Publications Ltd, 2016 